\title{
Venture Capital Financing and The Growth of Small and Medium Scale Enterprises in Calaber Metroplis, Cross River State, Nigeria
}

\author{
Mboto Helen Walter, Amenawo I. Offiong, Dr. Chris O. Udoka
}

\begin{abstract}
The major thrust of this work was to investigate the impact of venture capital financing on the growth Calabar metropolis Cross River State. The rationale for this study was to determine whether the use of venture capital finance, as one of the new sources of financing options by SMEs in Cross River State could create a significant impact on the growth of SMEs. In carrying out this work, a hypothesis was formulated. The financial contracting theory was adopted by the study. The exploratory research design was utilized. In the study, a non probability sampling method (purposive) was used. Using the Yamane formula, a sample of forty (40) SMEs from among the SMEs in Calabar metropolis was selected. The manager, accountant or account officer and secretary were purposively selected and included in the sample. Information were gathered with the utilization of organized solid and approved polls. An aggregate of 120 polls were directed, however 80 recovered. The information was examined with the utilization of various relapse investigation introduced in tables. The discoveries of this examination uncovered that there was a critical effect of investment back on the general development of SMEs in terms of record keeping, volume of business, access to other sources of funding, sales value, and net Assets. etc. Accordingly, the study recommended that awareness be created among SMEs on the existence and operations of venture capital as this could be one of the potent ways of boosting sustainable growth and stability of SMEs in particular and socio economic growth and development of the economy in general.

Index Terms - venture capital, SMEs growth.
\end{abstract}

\section{INTRODUCTION}

The existence of small and medium scale enterprises (SMEs) in a developing country like Nigeria is of great importance, as they promote and contribute to economic growth. Udechukwu (2003), found that, SMEs are not only contributing to improving the standard of living, but also increase local capital accumulations, which leads to high capacity building and productivity. This has made the government and non government organizations, as well as experts to recognize SMEs as the main engine of economic growth. This recognition notwithstanding, there is still low attention to SMEs, a consequence of which may be the slow

Mboto Helen Walter, Ph.D, , Department of Banking and Finance, University of Calabar, Nigeria

Amenawo I. Offiong, Ph.D, Department of Banking and Finance, University of Calabar, Nigeria

Dr. Chris O. Udoka. , Department of Banking and Finance, University of Calabar, Nigeria. development of the industrial sector in the State.(Udechukwu, 2003).

The concept of small scale enterprises varies from one country to another. Akinrinade (1989) view fifty different definitions on the concept of small scale industries by United Nation Industrial Development Organization (UNIDO) in seventy-five different countries. Such varied definitions were based on parameters such as installed capacity utilization, output, capital employment, type of industry considered more relevant to the industrial policies of the specified country.

Ayuba (1989) defines small businesses to embrace all manufacturing units with a total capital investment (excluding cost of land) up to 50 people. The Nigeria bank for commerce and Industries (NBCI) defines small scale industries as those investment rang from500,000 and above (excluding the cost of land but including working capital) and whose work force at the beginning stage of not be less than five employees.

Salami (2003), also maintained that the promotion of small and medium scale enterprises aids the dispersal and diversification of economic activities and induces even development in a country.

Olorunshola (2003) further maintained that small and medium scale enterprises need little capital to start operation and the availability of raw material in most countries made them very interesting. In addition, they are simple to manage and operate; thereby, making investment in this sector affordable to the ordinary people in the society. Small and medium scale enterprises are also noted for the preparation of residential funds for speculation, obvious adding to GDP, saddling of neighborhood crude materials, produce work, essentially adding to destitution diminishment endeavors through manageable vocation.

As indicated by Okpara and Pamela (2007), factors in charge of little and medium scale business disappointment in Nigeria incorporate; rivalry, absence of monetary help, administration encounter, foundation, preparing and sufficient book and record keeping. Different factors as announced are low interest for item or administrations, pulling back much money for individual utilize and absence of statistical surveying. Although this set of factors hinders 
the performance of small and medium scale enterprise for maximum contribution to the economy, it is in this regard that Sangosonya (2010) identifies ten key factors and variables influencing small and medium scale enterprise failure in Nigeria, these are disaster economy planning, taxes infrastructure, accounting management marketing and finances. Adelaja (2003), in examining the problems of small and medium scale enterprises segmented them into three phases, namely: The pre-investment phase, the investment phase, and the operating phase

Venture capital though a new concept in Nigeria has been existing in developed countries for years now, it has been known to add great value to the economic growth. It enhances the growth of SMEs by providing the needed capital and taking part in the management of the business. Result from European Venture Capital Association (2001), reveals that SMEs that are financed by venture capital added up to 46 jobs to the Nigeria economy. However, in Cross River State, the funding and utilization of venture capital are relatively new and impact greatly unnoticed. This research therefore, is an attempt at investigating whether funding financing improves the development of SMEs in Cross River State in particular and Nigeria general.

\section{STATEMENT OF THE PROBLEM}

Accessibility to finance is of great importance to the growth of Small and Medium scale enterprise. Small and Medium Scale Enterprises are always faced with the challenge of inadequate funding because of their inability to access credit from financial institutions. Since they have limited ways of accessing funds, they rely basically on their retained earnings for their investment, hence difficult to achieve growth and sustainable development.

Government in the past have had to introduce special programmes like: Small and Medium Scale Industries Development Agency (SMEDAN), Small and Medium Enterprises Equity Investment Scheme (SMEES), Small Industries and Credit Committee (SICC), the establishment of Industrial Development Centre,(IDC), the establishment of the National Directorate of Employment(NDE), Small Scale Industry (SSI), Youth Employment and Vocational Skill Development, Open Apprenticeship Scheme among others. These were introduced to stimulate the performance of SMEs, with a view to boosting, not just financing but management capacity of SMEs for economic growth and development.

Despite these programmes and policies, the growth of SMEs still remains unsatisfactory due to lack of funds for business operations. More worrisome is the fact that SMEs sprout up in their numbers and fail within a very short time. Therefore, inadequate funding and inability to access available funds constitute a major challenge to SMEs. The non availability of finance hinders the growth of the business in terms of their net asset, profit margin and sale volum.
Due to the above, SMEs in Nigeria and Cross River State in particular, have continued to remain underfunded; there is therefore the need to enhance the performance of SMEs since they should contribute meaningfully to economic development. When SMEs are properly positioned, they should bring about output expansion, employment generation, income redistribution, promotion of indigenous entrepreneurship and strengthen industrial linkage. Therefore, there is need to remedy and boost this very important and valuable sector of the economy. It's on this basis that this study seeks to investigate whether funding financing improves the development of SMEs in Cross River State.

\section{PURPOSE OF THE STUDY}

The main objective of this study is to examine whether venture capital financing enhances the growth of SMEs in Cross River State.

\section{Research hypothesis}

There is no significant impact of venture capital financing on the growth of SMEs in Cross River State.

2. Literature Review.

One of the major challenges of SME is on how to raise adequate funds to enable them operate more effectively and efficiently and contribute to poverty reduction (Memba, 2011). Consequent upon this, Countries of the world have adopted different strategies and reforms to finance and stimulate the activities of SMEs. Also, many progammes were established by the government to help in the area of finance, training, extension and advisory services for the development of SMEs (Orunshola 2003). These progammes and polices notwithstanding, financing challenges still stand on the face of Small and medium scale enterprises, particularly in developing countries. Finance plays a strategic role in the development and management of any business enterprise, because every business action has a financial effect on the firm. A manager's ability to obtain and use funds effectively is key to the success or failure of his business (Ile, 2001), Friend (1954), argued that, the success of a business is its ability and willingness to maintain production and this is determined by both the past and present financial policies of the firm.

Nwachukwu (2005) also argued that, one of the key questions that a prospective entrepreneur must ask is "how to finance an enterprise. Finance being the heart of all enterprises, an entrepreneur must seek out ways of raising funds for a new venture or keep the existing enterprise alive. Lack of proper financial intermediation mechanism that can direct resources into private productive investment has hindered the progress and potentials of SMEs. Inadequate credit and equity capital has also hindered the performance and the expansion of SMEs. Venture capital is a private or institutional source of finance that can provide large amount 
of capital to SMEs without requiring collateral. (Akintoye,2002). As an organized private or institutional financier, it provides substantial amount of capital mostly through equity purchase and occasionally through debt offering to help growth oriented businesses develop and succeed (Machiraju, 1996). Venture capital plays a strategic role in funding small and medium scale enterprises and high risk ventures especially in developed countries.(Machiraju, 1996).

Although in Nigeria, it is a relatively new source of funding that is impacting on the life of entrepreneurs. According to Memba( 2011), it referred to as a modern entrepreneurial financial innovation. It is viewed as the early stage financing of ventures or new enterprises that wants to grow. The prime motive of venture capital is to see to the growth of small enterprises to become big enterprises (Pandy, 2010).

Venture capital plays a strategic role in funding small and medium scale enterprises. It has taken roots in a number of developing countries. In Nigeria, It is relatively new and has not impacted so much in the life of entrepreneurs. According to Hisrich and Peters (2009), it is a professionally managed pool of equity capital that is frequently gotten from the resource of wealthy limited partners. Mucherjee (1999), also view venture capital as finance meant for the improvement of an ongoing business with good managerial and high growth potential.Venture capitalists and venture capital firms recognize that many or most new ventures will not succeed if adequate funding is not given to them. To limit their risk, venture capitalist generally provides finances in stages, at each stage; enough money is invested to reach the next mile stone or planning stage. Venture capital plays a strategic role in financing small and medium scale enterprises. It does this through early stage financing of the enterprises. Its main function is to see that the entrepreneur grows from a small to big a state, thus, for this basic function, venture capital have the primary responsibility of providing funds for the growth of small and medium scale enterprise.

Venture capitals have different funding ways, one of such ways according to Pandy (2010), is institutional speculators, These are comprised of annuity stores, insurance agencies and professionally oversaw, altruistic establishment/blessing asset of colleges, others are affluent people who are individuals from a business group; forceful daring individuals who have the astuteness to choose great endeavors with solid possibilities. Besides, there could be specific corporate associations set up to support new business wanders that do not have the ability to draw in financing from banks (Pandy, 2010).

In 2001, the European Venture Capital Association conducted a survey on SME which made use of venture capital finance and came out with the following results: (i)95percent SMEs would have collapsed or remained the way they started if venture capital funds were not given to them .(ii) 60percent of the SMEs population concluded that their continual stay in business, was as a result of their participation in venture capitalist funds.(iii) venture capital finances were more reliable than any other debt finance.(vi)The problem of non-payment of bank loan by SMEs because of stunted growth was off their face.(v) venture capital funding enabled SMEs to create forty-six additional jobs. The global insight (2001) as reported by the USA's National Venture Capital Association, pointed out that SMEs' were made use of venture capital employed more than 12 million persons and generated up to 3 trillion as revenue.

In a study on the effect of venture capital financing on the economic value added profile of Nigerian SMEs, by Daibi and Walter (2009) SMEs that are financed by venture capital were found to have perform better than non venture capital financed SMEs. Thus, the study attributed to the effect of management support by venture capitalist to SMEs portfolio. A study conducted by Udo (2010), on the performance of SMEs in Uyo Local Government Area of Akwa-Ibom , indicate that even if SMEs occasionally received support from financial institutions, SMEs will continue to rely on venture capital financing both at conceptual and expansion stage. Venture capital attracts other finance bodies to participate in financing SMEs; and venture capital provides partnership options which enables SMEs make financing decision and choices about their firm capital structure. Capital structure according to Orjih (2001), represented the relationship between debt and equity as an important tool in managerial decision. It revealed the different combination of debt and equity in the financing policy. Therefore, the effect of capital structure on the firm performance depends on the financing decision of the firm.

In a survey of the potency of venture capital financing in revamping SMEs, Memba, Gakure\&Karraja (2011) revealed that venture capitals have impacted on the growth of SMEs financed by them. The study "demonstrated that the use of venture capital can be profitable even in an unfavorable political and economic climate. The study maintained that SMEs which used venture capital experience improved growth" thus recommended that for the country to achieve her economic blue- print, articulated in her vision 2030 more SMEs must be encourage to seek funding from venture capitalists.

This study further revealed that the effort of venture capitalist in boosting SMEs growth is not just real but practical, hence increased venture capital financing improves SMEs credit rating, marketing and distribution network, technical expertise and managerial skill. An investigation into venture capital financing on SMEs in Bindura, Zimbawe by Manyani (2014) maintain that the financing options available to Bindura SMEs are impracticable to support their capital requirement for operating their businesses; therefore, the use of venture capital should be encouraged for improved SMEs performance in Zimbawe.

A survey on the need of venture capitalist in financing SMEs conducted by Kumar (2009), affirm "that venture capital financing tool is a suitable option to supply both the financing 
and non financing requirement of SMEs as they practice a participating management approach and exercise due diligence technique in disbursement of credit". Venture capital finance, in this work, is viewed as an institution that is not like other financial institutions which provide loan at a given interest rate.

This study is important because it seeks to provide useful information to managers of SMEs on the existence of venture capital financing as an alternative source of funding. The study will also seek to educate SMEs on how to apply for funding from venture capital firms. It will also enable policy makers to make sound and intelligent policies that will ensure the development of SMEs in Nigeria. Student and researchers will find this study as a useful referee's material in the field of finance. Notwithstanding, the study had it theoretical foundation on the financial contracting theory perspective, forward by Jensen and Meckling (1976), and subsequently validated by Watts and Zimmerman (1986). The theory state that every business requires accounting information in boosting or facilitating transactions between financiers and those requiring financing, where by funds and expertise are provided by the venture capitalist as a result of the available accounting information given by the entrepreneur. The theory can be used to explain the relationship between venture capitalist and entrepreneurs. The theory states that given a variable project but no availability of funds a financier could provide the funds needed for the project.

\section{An over view of venture capital}

Venture capital is a type of financing for another or developing business. It for the most part originates from firms that work in building high hazard monetary portfolios. The financial speculator offers subsidizing to the new company in return for value in the startup. Funding is cash furnished by speculators to new companies with apparent long haul development potential (lnvestopedia, 2012) Venture capital plays a strategic role in funding small and medium scale enterprisess. It has taken roots in a number of developing countries. In Nigeria, It is relatively new and has not impacted so much in the life of entrepreneurs. Pandey (2002), affirms that venture capital is an important funding innovation of recent described it as high risk capital. It is often seen as the early stage financing of ventures or new enterprise that want to grow. According to him, the prime motive of venture capital is to see small enterprises grow to big enterprises.

Akintoye (2002), defines it as an engagement by the venture capitalist in the management of the client enterprise. $\mathrm{He}$ further argues that venture capital is the commitment of long term equity capital where the venture capitalist make his profit in the form of capital gain. The underlying assumption, according to him, is that the entrepreneur and the venture capitalist act as partners. To him, venture capital is a powerful mechanism that can institutionalize innovative entrepreneurship. In fact, it is a commitment of capital or shareholding for the formation and setting up of small and medium scale enterprises with focus on the business growth. According to Hisrich and Peters (2009), it is a professionally managed pool of equity capital that is frequently gotten from the resource of wealthy limited partners. Ross, Western, and Jordan (2009), view venture capital as the financing for new, often high risk ventures. Mucherjee (1999), also view venture capital as finance meant for the improvement of an ongoing business with good managerial and high growth potential.Venture capitalists and venture capital firms recognize that many or most new ventures will not succeed if adequate funding is not given to them. To limit their risk, venture capitalist generally provides finances in stages, at each stage; enough money is invested to reach the next mile stone or planning stage.

Nwachukwu (2005), defines venture capitalist as the provider of equity financing that make money available to both new ventures and existing ventures. Lerner (2000), argued that it is an equity investment for new private companies in which the investor is seen as a financial intermediary acting as a director, adviser and a manager of the enterprise. William (2004), defines it to mean a process whereby investors commit their fund to early stage and more risk oriented firms. From Cumming and Malcntosh (2011) it is financial intermediaries whose contribution comes from institutional investors or wealthy individuals in the economy who wish to invest the fund in small private and high technology enterprise.

Willam (2004), affirms that it is a funding institution that is quite different from the traditional way of financing. By this, he means that they can be viewed as follows, they are: investors who provide fund to new and promising enterprise; they provide fund for startup and emerging firms without demanding for collateral; it's an investment that requires a higher rate of output so that the business can stand within three to seven years period before public offer may be made etc.

Rose and Wester (1990) argued that venture capital is another form of equity financing for SME's. Therefore, it is also seen as a process in which investors are given the early stage support to new venture. Venture capital is defined as money that is made available by venture capitalist to set up or start up firm and small businesses with a long term growth potential.It is an important source of funding startup business that cannot access fund in the capital market. It is actually a high risk business for investors with a potential high returns. Venture capitalist works with managerial and technical expertise that originated from group of wealthy investors, investment banks and financial institution that pools their resources together with the aim of helping young enterprises. Mason (1996) in his study on the process of accruing funds from venture capital firms found out that the common approach is first of all to furnish venture capitalist with a copy of business plan. If they accept the plan then there is an 
opportunity on what the company has to offer, that, is management and also to market to them a product service with a lot of potentials. It is just like any other sales job; display the wares and convince them that there is something they need. The venture capitalist has to understand your business and gain the feeling for the enthusiasm that backs it. The venture's challenge is to get them personally involved, to buy into their determined dedication. SMEs need to be emotionally involved aside providing a business plan. SMEs' seeking for equity should be caution about how they present their expected projection. The projections should be realistic and achievable. A relationship between the firm and venture capitalist is established with a strong bond of good faith and that one earnestly attempts to keep all commitments (Sohl, 2003). This shows that transparency is the key to their managerial service. Therefore, Venture capital, as an early stage financing of new and growing enterprise needs more awareness for our young entrepreneurs to embrace and grow. (William, 2004).

\section{HISTORICAL PERSPECTIVE OF VENTURE CAPITAL} FINANCING IN DEVELOPED AND DEVELOPING COUNTRIES

In Nigeria, the rise of venture capital industry align with the works of RotimiOyekanmi, on the historical perspective of venture capital industry in Nigeria, to be a significant contribution in the growth of small and medium scale enterprises. Ben,(2000), reported that Rotimi in his work suggested three eras, the pre era of 1997, 1998 to 2002 the second era and 2003 till today era. The pre 1997 era was the first era of venture capital (incentives) 1993 act that approved the making of the National Risk Fund plc built up in 1987 In Nigeria, we have the principal investment firm settled by the government through the new material Research Development Council (RMRDC) and other offer holding part like bank and assembling organizations.

The period additionally displayed the part of Development Financial Institutions (DFIs) in rise of investment in Nigeria. They had a noteworthy influence in making the human information and taking in base from which the soonest funding drew. This time likewise acquired two unmistakable endeavors capital Nigeria. They were the National Risk Fund Plc, and Venture and Trust Company. The significant worry of that period incorporates the presentation of formative budgetary establishment (DFIs); the association of Commercial banks in financing real government interest in substantial industry e.g. (steel, aluminum, manure and so forth.); nearness of white relentless undertaking.

1998 to 2002 time was on funding approach on little and medium scale ventures (SME), here, banks in Nigeria were willfully required to set aside $10 \%$ of their benefit after duty (PAT) for speculation and advancement of little and medium endeavor plot. This period likewise achieved the amalgamation of first finances, SME supervisor, UBA private value, and in-house private value unit inside bank. In this time of 1998, the military were still in control and on account of that we had privatization of government possessed firm crosswise over money related administration, oil and gas and furthermore the urbanization of the media transmission segment. These adjustment in possession required long haul hazard capital, which just investment firm could give. This brought the section of worldwide investment like Actis and Aureus capital .Ben (2002). African capital partnership developed a pre-prominent nearby investment firm amid this time. 2003 to date; the third era is the mostimportant era. In this era, the venture capital sector is more recognized as it becomes part of the Nigeria financial sector with a constant search for opportunities across the entire business environment. The country is enjoying growth in the activities of small and medium scale enterprises and indeed the economy, as a result of the identification of venture capital Ben (2002). The emergence of venture capital in developed societies, like the United States dated back as far as the Second World War. Hisrich and Peter) point out that in the United States, venture capital throughout the industrialization period was very significant, but was internationalized after the Second World War. Before this time, it was seen as a venture investment that is made by wealthy persons, merchant and a few organizations with trained managers. The first move to institutionalized venture capital initiative was in 1946 with the establishment of the American Research and Development Corporation (ARD) in Boston. The aim of the American Research and Development Corporation was to pull capital from individuals and institutions together by General George donor to promote active investment in picking out emerging business.

The Small Business Investment Company Act of 1958 was the next major development of venture capital that struggle to merge private fund with government funds. These funds were to be used by trained managers of small business investment firms to enable them allocate capital into new businesses that are starting up and growing small business, with freedom from tax payment, government funds for leverage and status as a private capital firm. Venture capital firms started formally as SBIC.

Hisrich and Peter (2003) affirm that in 1960, there was a great SBIC, with the authorization of about 585 SBIC licenses that involved more than 205 million US dollars in private capital. But because of inexperienced managers, a focus on short term profitability, poor result, and over regulation by the government, the SBIC collapsed and the programme was restructured which helps to reduce some of the unwanted government regulation and the amount of capital needed was increased. According to Hirsch and Peter (2003), there are almost 360 SBIC in operation. In 1960, there was the emergence of small private venture capital firms. Seen as limited partners with the venture capital firms standing as the general partners with a management fees and percentage accorded to him as profit.

In India, according to Pandy (2010), the activity of venture capital industry is more than a decade, but it has not been 
fully developed, so as it is, it required more effort and policy initiatives to grow. Venture capital was formally introduced in India in 1987 at the creation of the venture funds which was announced by the government to be operated and managed by the Industrial Development Bank of India (IDBI). For them to create venture capital fund, all import payment were levied 5\%. Also, in that same year, the Industrial Credit and Investment Corporation (ICIC) started its own venture capital and floated a separate venture capital firm known as Technology Development and Information Corporation (Pandy, 2010).

Venture capital firm in India were grouped as: The venture capitals funds that is promoted by the federal government which induce risk capital and technology, the state owned promoted venture capital funds, the venture capital promoted by the public and one promoted by the foreign banks and private sector companies and financial institutions. According to Pandy (2010) these have led to a steady increase in the number of venture and the amount created by venture capital. In Europe, However, countries like UK, Western Europe and Japan witnessed a widespread of venture capital firms which made developed markets to be more saturated and so many developing nations were more aggressive in regulatory reforms that make them to be ready for investment.

Ooghe, HmanigartFassia (1991) and (Gmopers and lerner 1998) also affirm that in places like Singapore, Taiwan and Hong Kong, the activities of venture capital market are well established. While in Poland and Hungary, the growth of venture capital activities was overwhelming. China was not left out as venture capital went on well (Ulright, kissane and burrow, 2004). Through International Finance Corporation, the World Bank was able to establish venture capital in some African countries like Kenya, Brazil, and South Africa and also in Eastern Europe and Asia (Inbona, 2002). In Kenya, according to Memba (2011), venture capital has contributed greatly to the growth of SMEs.

\section{VENTURE CAPITAL AND ITS IMPACT ON THE PERFORMANCE OF SMALL AND MEDIUM SCALE ENTERPRISE}

Venture capital plays a strategic role in financing small and medium scale enterprises. It does this through early stage financing of the enterprises. Its main function is to see that the entrepreneur grows from a small to big a state, thus, for this basic function, venture capital have the primary responsibility of providing funds for the growth of small and medium scale enterprise.

Venture capitals play a significant role in the growth of small and medium scale enterprises by participating fully in the management of the enterprise, checkmating the activity of SME and taking part in the operationprocess. It helps with giving seed cash-flow to new businesses with a view to helping the business person accomplish continuous concerns status before having the capacity to draw in bank financing. It gives hazard cash-flow to a current SME as help in a time of quick development, or encourages the presentation of another item into the market. It adds to GNP/GDP of the economy through yield development.

Investments have diverse financing courses, one of such routes as indicated by Pandy (2010), is institutional speculators, These are comprised of benefits stores, insurance agencies and professionally oversaw, magnanimous establishment/gift reserve of colleges, others are affluent people who are individuals from a business group; forceful daring people who have the intuition to choose great endeavors with solid possibilities. Moreover, there could be particular corporate associations set up to subsidize new business wanders that do not have the ability to pull in financing from banks (Pandy, 2010).

\section{RESEARCH METHODOLOGY}

The study adopted an exploratory research design. The area for this study isCalaber metropolis, Cross River. One hundred and twenty 120 respondents comprising of managers, accountant/account officers and secretaries from Forty (40) SMEs in the metropolis which have used venture capital funds were purposively selected from a total of forty five (45) SMEs to participate in the study. For ease of understanding, the population and sample distribution is presented in Table 1 . A validated research made questionnaire was used for data collection in the study. The instrument had a five-point rating scale of: Strongly Agree (SA), Agree (A), Disagree (D) Strongly Disagree (SD) and Undecided (U) with corresponding scores of 5, 4, 3, 2 and 1 and reversed for all positively and negatively worded items respectively. A reliability index of .92 was achieved for the instrument using Spearman Rank Correlation, after trial testing the instrument on 30 respondents from the study area that were not part of the main study. The researcher personally administered 120 copies of the instrument to the respondents in the study area and retrieved 80 copies of the instrument after responding to it. Data collected were analyzed using multiple regression analysis output to test the null hypotheses at 0.05 level of significance. 
TABLE 1

Population and sample distribution of SMEs in Calaber metropolis, Cross River State

\begin{tabular}{lll}
\hline Etagbor & 6 & 5 \\
Calabar road & 5 & 4 \\
Marian road & 6 & 5 \\
8 mils & 6 & 6 \\
imbupka & 3 & 3 \\
MCC & 7 & 6 \\
Atimbo & 6 & 6 \\
Ediba & 6 & 5 \\
Total & 45 & 40 \\
\hline
\end{tabular}

Field work (2017)

TABLE 2

Growth of SMEs before use of venture capital

\begin{tabular}{|c|c|c|c|}
\hline Model & $\begin{array}{c}\text { Variables } \\
\text { Entered }\end{array}$ & $\begin{array}{c}\text { Variables } \\
\text { Removed }\end{array}$ & Method \\
\hline 1 & $\begin{array}{c}\text { volbiz, netasset, }^{\text {turnover }}{ }^{\mathrm{b}} \\
\text { turiablem }^{\mathrm{a}}\end{array}$ &. & Enter \\
\hline
\end{tabular}

a. Dependent Variable: profit

b. All requested variables entered.

Model Summary

\begin{tabular}{|c|c|c|c|c|c|}
\hline Model & $\mathrm{R}$ & $\mathrm{R}$ Square & $\begin{array}{c}\text { Adjusted R } \\
\text { Square }\end{array}$ & $\begin{array}{c}\text { Std. Error of the } \\
\text { Estimate }\end{array}$ & Durbin-Watson \\
\hline 1 & $.742^{\mathrm{a}}$ & .694 & .529 & 0.20119 & 1.714 \\
\hline
\end{tabular}

a. Predictors: (Constant), vobiz, netasset, turnover

b. Dependent Variable: profit

\begin{tabular}{|c|c|c|c|c|c|c|}
\hline \multicolumn{7}{|c|}{ Coefficients $^{a}$} \\
\hline \multirow{2}{*}{\multicolumn{2}{|c|}{ Model }} & \multicolumn{2}{|c|}{ Unstandardized Coefficients } & \multirow{2}{*}{$\begin{array}{c}\text { Standardized } \\
\text { Coefficients } \\
\text { Beta }\end{array}$} & \multirow[t]{2}{*}{$\mathrm{t}$} & \multirow[t]{2}{*}{ Sig. } \\
\hline & & $\mathrm{B}$ & Std. Error & & & \\
\hline \multirow{4}{*}{1} & (Constant) & 3.321 & 2.885 & & 1.151 & .302 \\
\hline & Turnover & .107 & .928 & .023 & .654 & .542 \\
\hline & Netasset & -.321 & .729 & -.207 & -.441 & .677 \\
\hline & Vobiz & -.214 & .746 & -.167 & -.287 & .785 \\
\hline
\end{tabular}




\section{RESULTS}

\section{General description of research variables}

To establish the growth of SMEs in Calabar metropolis the study made use of the following variables, volume of business, sales/turnover, netassets and number of employee to represent the growth of the SMEs. The dependent variable was measured as the profit of the SMEs over the period. Hence, this section presents the regression result of the growth of the SMEs before the use of venture capital.

PERF $=\alpha_{0}+\alpha_{1}$ VOLBIZ $+\alpha_{2}$ NETASSET $+\alpha_{3}$ TURNOVER

The $R^{2}$ of the result often called the coefficient of determination which measures the fitness of the model. This result could be interpreted that the variable of volume of business, net assets, number of employee and turnover had a
69 percent deviation with the dependent variable (growth of SMEs). The economic interpretation of the result indicates that a unit change in the volume of business will enhance a 10 percent increase in SMEs profit. A unit increase in net assets and number of employees reduces the SMEs profit by 32 percent. Similarly, a unit increase in turnover reduce SMEs profit by 21 percent. The overall result of the impact of growth of SMEs before the use of venture capital indicate that, while volume of business increased SMEs growth by a mere 10 percent, their net assets, number of employees and turnover were observed to reduce SMEs profits by 32 per cent and 21 per cent respectively. The result further observed that all the independent variables did not show evidence of having significant relationship with SMEs profitability: volume of business $(\mathrm{p}=1.783>0.05)$, net asset $(\mathrm{p}=$ $0.677>0.05)$, turnover $(\mathrm{p}=0.542>0.05)$.

TABLE 3

Growth after the use of venture capital Variables Entered/Removed ${ }^{\text {a }}$

\begin{tabular}{|l|l|l|l|}
\hline Model & \multicolumn{1}{|c|}{$\begin{array}{c}\text { Variables } \\
\text { Entered }\end{array}$} & $\begin{array}{l}\text { Variables } \\
\text { Removed }\end{array}$ & Method \\
\hline 1 & $\begin{array}{l}\text { volbiz, } \\
\text { turnover, }^{\text {netasset }}{ }^{\mathrm{b}}\end{array}$ & & Enter \\
\hline
\end{tabular}

a. Dependent Variable: Profit

b. All requested variables entered.

\begin{tabular}{|l|r|r|r|r|c|}
\hline Model & $R$ & $R$ Square & $\begin{array}{c}\text { Adjusted R } \\
\text { Square }\end{array}$ & $\begin{array}{c}\text { Std. Error of } \\
\text { the Estimate }\end{array}$ & $\begin{array}{c}\text { Durbin-Watso } \\
n\end{array}$ \\
\hline 1 & $.772^{\mathrm{a}}$ & .651 & .622 & .00386 & 2.305 \\
\hline
\end{tabular}

a. Predictors: (Constant), vobusiness, turnover, netasset

b. Dependent Variable: Profit

Coefficients $^{a}$

\begin{tabular}{|c|c|c|c|c|c|c|}
\hline \multirow{2}{*}{\multicolumn{2}{|c|}{ Model }} & \multicolumn{2}{|c|}{ Unstandardized Coefficients } & \multirow{2}{*}{$\begin{array}{c}\text { Standardized } \\
\text { Coefficients } \\
\text { Beta }\end{array}$} & \multirow[t]{2}{*}{$\mathrm{t}$} & \multirow[t]{2}{*}{ Sig. } \\
\hline & & $B$ & Std. Error & & & \\
\hline \multirow{4}{*}{1} & (Constant) & 3.390 & 1.236 & & 2.742 & .041 \\
\hline & Turnover & .463 & .044 & .775 & 10.522 & .000 \\
\hline & Netasset & .317 & .082 & .362 & 3.865 & .014 \\
\hline & Volbiz & .246 & .014 & .245 & 17.571 & .000 \\
\hline
\end{tabular}

a. Dependent Variable: Profit
PERF $=3.390+$
(2.742)
0.463 Turnover +
0.317 Netasset +0.246 Volbiz
(10.522)
(3.865)
$(17.571)$ 
A high correlation coefficient was established between SMEs growth and the other independent variables. This correlation coefficient explains that the independent variables accounted for 77 per cent deviation in SMEs performance. The coefficient of the constant term revealed that holding all other variables constant SMEs will experience a growth of 3.390. The coefficients of turnover, net assets number of employees and volume of business all exerted positive effect on SMEs growth. For instance, a unit increase in turnover after the use of venture capital will increase SMEs growth by 46 per cent. A unit increase in net assets will also increase SMEs growth by 31 per cent. The result also revealed that a unit increase in volume of business increases SMEs growth by 24 percent. This result implies that growths of SMEs are enhanced following their ability to access funds from venture capital. The result further established that a significant relationship exist between turnover, net assets and volume of business, turnover $(\mathrm{p}=000<0.05)$, net assets $(\mathrm{p}=0.014<0.05)$ and volume of business $(\mathrm{p}=0.000<0.05)$. This result amplifies that fact that venture capital significantly impacts on the performance of SMEs.

\section{TEST OF HYPOTHESES}

There is no significant impact of venture capital finance on the growth of SMEs in Calabar metropolis .

Decision Rule: the study will reject the null hypothesis if the Tcal>Tcrit. Otherwise, the study will accept the null hypothesis if Tcal<Tcrit.

In order to test the significant impact of venture capital finance on the growth of SMEs, the study will adopt the $\mathrm{t}$-statistics test. If the value of the critical t-statistics is greater than the tabulated value of the standard t-statistics, we will reject the null hypothesis and accept the alternative hypothesis, thus, suggesting that venture capital has a significant impact on the growth of SMEs. Thus, from the result it is observed that the Tcal (2.495) for the coefficient of growth is greater than the Tcrit (1.87). Thus, the study concludes that there is a significant impact of venture capital on the growth of SMEs in Calabar metropolis Cross River State.

\section{DisCUSSION OF FINDINGS}

The study noted that before the use of venture capital the coefficient of growth of SMEs was 11.6 percent indicating that a unit change in venture capital finance will increase the growth (net assets, turnover and volume of business) SMEs by 11 percent. However, the $\mathrm{p}$-value for the growth variable was insignificant indicating that although the growth of SMEs was not significant in enhancing the growth of SMEs in Calabar metropolis Cross River State. The result of the performance of the SMEs after the use of venture capital indicated that there was a marked improvement in the performance of SMEs. The result also showed that there existed a positive and significant relationship between venture capital financing and the growth of SMEs. The result indicated that a unit change in venture capital financing will increase SMEs growth by 71.8 percent. This is to say that venture capital financing has a significant impact in increasing the net assets, turnover and volume of business of SMEs in Cross River State. A look at the growth model after the use of venture capital finance seems to reveal some basic truth. Out of the variables that were responsible for the growth ofSMEs (net asset, turnover, volume of business), after the use of venture capital revealed that turnover and net asset contributed 46 per cent and 31 percent respectively. The growth of SMEs has been stunted previously due to lack of funds. The little funds available to the SMEs were not sufficient to attract the required volume of business. However, with the assistance of venture capital financing SMEs began to experience increase in their acquisition of assets, improvement in business turnover and explosion in the volume of business.

\section{CONCLUSION}

Given the discussion above the following conclusions are inferred from this study: Venture capital financing contributes greatly to the growth, of SMEs inCalaber metropolis Cross Rive State. The various results of SMEs performance after the use of venture capital suggest that venture capital acts as a very big leverage necessary for the growth and progress of SMEs in Cross River State.

\section{RECOMMENDATIONS}

Based on the above conclusion the study made the following recommendations

1. Venture fund managers should periodically assess the books of accounts and the administrative records of the SMEs under their purview to determine the state of debt management ability. This will enhance profitability and performance of small and medium scale enterprises.

\section{REFERENCES}

[1] G Akinrinade, A. (1989). Small Scale Enterprise: Backbone of Industrialization, the Nigeria Entrepreneur, Lagos 2(1)5-6.

[2] Akintoye, I. R. (2002).Investment Decision Concepts Analysis and Management.Ibadan,Glorious Hope publishers.

[3] Ayuba , S. (1989 January 29). Management strategy on small Scale Business. The weekly Democrat.

[4] Daibi,W,D. \& Walter,G,O. (2009). The Effect of Venture Capital Financing on the Economic Value Added Profile of Nigeria SMEs. African Journal of Accounting, Economics, Finance andBankingResearch5(5) Retrieved from http://papers.ssrn.cm/so13/papers.cfm?abstract id1534211.

[5] European Venture Capital Association, (2001).Year Book European private equity and venture capital Association, Belgium.Zaventem. Internationals Journal of Business and Social Science 3(21) Retrive from www.ijbssnet.com.

[6] Friend, I. (1994). What business can prevent recession process in intercession policy. New York: Holotdinehand and wonston.

[7] Global insight, (2001).A report by the global insight (2001) USA.

[8] Hisrich, D. R., Peter, P.M. \& Shepard.P. (2009).Entrepreneurship. (Africa ed). Mc.Grew-Hill Custom publishing.

[9] Ile, M.N. (2001). Entrepreneurship development.The Nigeria perspective. Enugu:Chizugo venturepublishing.

[10] Machiraju, H.R. (1996). Project finance, Delhivikas, publishing, house PVT. Ltd.

[11] Manyani, O. (2014). An Investigation into Venture Financing.A Case Study on Small to Medium Scale Enterprise in Bindura Urban Zimbawe.Elite Research Journal of Accounting and Business Management2(2) 10-25

[12] Memba, S. F., Gakure, W. R. \&Karanja, K. (2011). The Impact of Venture Capital Finance on the Performance of Small and Medium Enterprise in Kenya. International Journal of Business and Social Science .3(6) 00200-6200 Retrieved from http://vc4africa.biz/wp-content/uploads/2012/...VC-kenya-Repot.pdf.

[13] Memba, S. F. (2011). The Impact of Venture Capital finance on the Performance of Small and Medium Enterprise in Kenya. International Journal of Business and Social Science.3(6) 00200-6200 Retrieved from

http://vc4africa.biz/wp-content/uploads/2012/...VC-kenya-Repot.pdf.

[14] Mucherjee, M. (1999, April 13). The venture capitalist as a possible financier,p10. 
[15] Nwachukwu, C.C. (2005). The practice of entrepreneurship in Nigeria, Onitsha, Nigeria: Africana-fish publishing.

[16] Okpara, U.\& Pamela, O. (2007). The role of Commercial Banks in Financing Small and Medium Scale Enterprise towards Achieving Development in Nigeria. (Unpulishedmasters thesis) University of Calabar, Nigeria.

[17] Olorunshola, J. A.(2003). Problems,

prospectofsmallandmediumscaleIndustryinNigeria, proceeding of the Central Bank of Nigeria, Nigeria.

[18] Pandy, I.M. (2010). Financial Management (11th ed.).Indian, vikas publishing hour PVC Ltd.

[19] Salami, N. A. (2003).Entrepreneurship simplified. Nairobi: saleemi publication Limited.

[20] Sangosanya, I. M. (2010). The Role of Commercial Banks in Financing Small Scale Business in Nigeria, Mina. Publication Limited.

[21] Uduchukwu, F. (2003).Survey of small and medium scale industry and their Potential in Nigeria, paper presented at the CBN. Seminar on small and Medium industries equity and investment scheme (SMIEIS). 